6. Kachkan, V. A. (1995). Ukraïns'ke narodoznavstvo v imenah [Ukrainian ethnology in names (Ch. 2)]. Kiïv: Libid'.

7. Kichura, L. Ideya derzhavnosti v publicistici Mikoli Golubcya (za materialami presi) [The idea of nationhood in the journalistic writings of Mykola Holubets (press release)]. URL: file:///C:/Users/\%D0\%9B\%D1\%8E\%D0\%B4\%D0\%BC\%D0\%B8\% D0\%BB\%D0\%B0/Downloads/5187-10228-1-PB.pdf

8. Savic'kij, R. (1993). Mikola Golubec': stisla bibliografiya [Mykola Holubets: concise bibliography]. Mistec'ki studiï, 2/3, 70-74.

9. Svarnik, I. (2002). Golubec' Mikola [Mykola Holubets]. Dovidnik z istoriï Ukraïni (A-Ya). Kiïv: Гeneza.

10. Svarnik, I. (2000). Ukraïns'ka shlyahta v doslidzhennyah Mikoli Golubcya [Ukrainian gentry in the research of Mykola Holubets]. Genealogichni zapiski Ukraïns'kogo geral'dichnogo tovaristva, 1, 47-49.

11. Stefanishin, T. (2004). Hudozhnya kritika Mikoli Golubcya u konteksti mistec'kogo procesu L'vova 1920-1930-h rr. [Art criticism of Mykola Holubets in the context of the artistic process of Lviv 1920-1930-ies.]. Visnik L'vivivs'koï akademiï mistectv: zb. nauk. prac', 14, 222-236.

УДК $930(19 / 20)$

\title{
ПОЛЬСЬКЕ ЗЕМЛЕВОЛОДІННЯ ПРАВОБЕРЕЖНОЇ УКРАЇНИ У ПРАЦЯХ ДОРЕВОЛЮЦІЙНИХ ДОСЛІДНИКІВ
}

\section{Стоберська Надія}

Статтю присвячено аналізу праць дореволючійного періоду з проблеми польського землеволодіння в губерніях Правобережної України. Входження регіону до складу Російської імперії змінило становище польських землевласників, що сприяло зростанню зацікавленості дослідників дореволюиійної доби до його історії та тогочасного стану. Доробок авторів того покоління становить інтерес, оскільки вони досліджували сучасне їм явище. Метою цього дослідження є аналіз праць, створених у другій половині XIX-на початку XX cm., з проблеми польського землеволодіння в украӥнських губерніях. Стаття спирається на приниипи наукової об 'єктивності та історизму, у процесі ї̈ написання застосовані аналітико-синтетичний, статистичний, історико-типологічний методи. Основу розвідки склали праці дореволючійних авторів, серед яких переважають історики та економісти.

Висвітлено погляди дослідників другої половини XIX-початку XX cm. на походження, становище, еволюцію польського землеволодіння. Показано, щчо дореволюиійні дослідники акцентували увагу на дворянсько-поміщицькому господарстві Росії, тоді як польське згадувалося лише в його контексті, зокрема в частині законодавчого забезпечення обмеження польського впливу та зменшення їхнього землеволодіння. Характерною особливістю дореволючійних досліджень стало те, щуо в них зосереджений великий масив статистичного матеріалу щьоо землеволодіння Правобережної України.

Ключові слова: польське землеволодіння, Правобережна Україна, дореволючійні дослідники, історіографія. 
Соціально-економічний розвиток українських губерній у складі Російської імперії був тісно пов'язаний з еволюцією польського землеволодіння, що до початку $\mathrm{XX}$ ст. домінувало на Правобережній Україні. Адже основним масивом українських земель на Правобережній Україні володіли польські магнати Потоцькі, Браницькі, Любомирські та інші. Навіть незважаючи на істотні земельні втрати внаслідок обмежувальної політики царської адміністрації польські магнати зберігали визначальні позиції в аграрному секторі аж до революційного 1917 р., що позначалося на соціальноекономічному становищі регіону. Вивчення польського землеволодіння розпочалося вже у XIX ст. Доробок авторів того покоління становить інтерес, оскільки вони досліджували сучасне їм явище.

Сучасні науковці зверталися до аналізу поглядів дореволюційних авторів щодо польського землеволодіння в українських губерніях. С. Борисевич, І. Кривошея, В. Лук'яненко, Н. Темірова, Н. Щербак та інші в контексті опрацювання ширших історичних проблем вивчають доробок дореволюційних авторів щодо вивчення історії польського землеволодіння $[3 ; 7 ; 9 ; 14 ; 16]$. Спеціальні історіографічні дослідження здійснені А. Криськовим, С. Бараненко та іншими [2; 8]. Незважаючи на інтерес науковців до історіографічного виміру історії польського землеволодіння, кожен 3 них вивчав його дотично. Тому наразі є потреба акцентувати увагу на поглядах дореволюційних авторів, які стояли біля витоків опрацювання цього явища в аграному секторі України. Метою цього дослідження є аналіз праць, створених у другій половині XIX - на початку XX ст., з проблеми польського землеволодіння в українських губерніях. Стаття спирається на принципи наукової об'єктивності та історизму, у процесі її написання застосовані аналітико-синтетичний, статистичний, історико-типологічний методи. Основу розвідки склали праці дореволюційних авторів, серед яких переважають історики та економісти.

Говорячи про польські впливи в українській історії, передусім, варто звернутися до поглядів визначного історика Володимира Антоновича. Незважаючи на материнське виховання, у нього сформувалося відторгнення польських звичаїв і традицій. Польські повстанці намагалися залучити вченого до виступу 1863 р., але той заявив про свою непідтримку польської шляхти з огляду на несприйняття ії українськими селянами. Найвиразніше ставлення до польського елементу В. Антонович виклав у праці «Моя сповідь», що з'явилася як відповідь на відкритий лист польського публіциста Зенона Фіша, який під псевдонімом Тадеуша Падалиці помістив його в «Основі», називаючи В. Антоновича «перевертнем». Історик пояснив причину його розриву з польською шляхтою, яку вважав поневолювачем українського народу. Автор у загальних рисах окреслив процес покріпачення українського селянства польською шляхтою. Він вважав, що цей вплив негативно позначився на українському населенні, відкидав саму думку про можливість добрих стосунків між польською шляхтою та селянством $[1,80]$. В. Антонович звернувся до візаві із закликом не заманювати українців польськими вольностями: «Кожух, може, й теплий, та не нас шитий» $[1,84]$. Відповідаючи Падалиці, автор наголосив на необхідності самоусвідомлення поляками власного становища, відзначивши, що воно безвихідне, якщо 
не відмовитися від посягань на українські землі. На його думку, існувало два шляхи вирішення «польського питання»: полюбити український народ, перейнятися його інтересами або ж переселитися на польську територію. Що ж до своїх переконань, то В. Антонович сформулював їх у такий спосіб: «... сподіваюся, що працею і любов’ю заслужу коли-небудь, що українці визнають мене сином свого народу, так як я все готовий розділити 3 ними» $[1,90]$. I висловив сподівання щодо повороту польського шляхетства до народу та усвідомлення необхідності працювати на його користь.

Історія польського землеволодіння в українських землях $є$ складовою наукової концепції М. Грушевського, який до цієї проблеми звернувся ще у своїй магістерській дисертації «Барское староство. Исторические очерки (XV-XVIII вв.)», а згодом розвинув у пізніших працях, зокрема у десятитомній «Історії України-Руси» [4; 5]. М. Грушевський зазначив, що в українських землях, підлеглих Польській короні, шляхетство сформувалося не відразу, певне підгрунтя було створене за литовської доби. Польська шляхта володіла цими землями на правах абсолютної власності, тобто мала право вільно розпоряджатися своїми землями і право спадку як з жіночого, так і з чоловічого боку. Далі шляхетські землі було звільнено від усіх служб, податків і повинностей, крім річної плати із залюдненої землі. Автор зауважив, що шляхта руських земель не мала самоврядування, яке існувало в коронних землях. Особиста свобода їі обмежувалася примусовим проживанням на певній землі, без права вільного розпорядження маєтками [5]. Вивчаючи колонізацію південно-східного Поділля, історик зазначив, що на відміну від литоських князів польські королі земельні пожалування роздавали представникам не місцевого населення, а полякам та їхнім прибічникам. М. Грушевський привернув увагу до того, що польські колонізатори отримували найродючіші в регіоні землі, підтвердженням чого стала відсутність у джерелах згадок про отримання ними пустирних ділянок.

Найвища колонізаційна енергія польського уряду припала на другу чверть XV ст., з середини століття її темпи скоротилися. Наступне піднесення польської колонізації припало на межу XVI-XVII ст., чому сприяло посилення обороноздатності регіону та формування достатньо багаточисельної когорти безземельних шляхтичів [4, 59-60, 124]. При роздачі земель Польська корона мала на увазі не стільки заселення краю, як посилення польського елементу [4, 59]. М. Грушевський зазначає, що передача полякам населених маєтків могла відбуватися двома шляхами: переведенням вільних сільських общин у залежність до шляхтича або реквізиція майна місцевих і пожалування їх полякам $[4,61]$. Уже в першій половині XV ст. відбувалися пожалування вже заселених територій внаслідок значного рівня залюдненості Поділля $[4,56]$. Поступово на зміну дрібному польсько-шляхетському землеволодінню прийшли магнатські латифундії. Як наслідок, регіон перетворювався в комплекс кількох латифундій, в які входили нечисельні маєтки дрібних власників [4, 151]. Отже, М. Грушевський відстежив витоки польського землеволодіння на українських територіях.

Інша група досліджень має соціально-економічне спрямування та належить правникам, економістам. Достатня увага приділялася впливу російського законодавства на позиції польських землевласників. Російське законодавство щодо українських земель 
проаналізував чиновник-українофіл Іван Рудченко. Обіймаючи посаду чиновника для особливих доручень при генерал-губернаторі, він підготував ряд записок-досліджень про особливості землеволодіння у Правобережних землях. Зокрема він проаналізував російське законодавство стосовно польського елементу після поділів Речі Посполитої. Автор показав, що законом 27 березня 1793 р. російської адміністрації підтверджувалися права і переваги кожного на рухому та нерухому власність, як і за коронного періоду. Виняток був для тих осіб, які відмовлялися від присяги, вони мали протягом трьох місяців продати майно та виїхати за межі Російської імперії. Якщо термін збігав, майно таких осіб належало до секвестру та передавалося до державної скарбниці. Автор зауважив, що в результаті за польськими землевласниками затверджувалося їхнє право на земельну власність 3 кріпосним населенням. Рескриптом 19 квітня 1794 р. за польським шляхетством було підтверджено право користування, «яко неотьлемою собственностію», казенним майном, розібраним шляхтою ще 1775 р. Як наслідок, польська шляхта, спираючись на привілеї з боку російського керівництва, зміцніла і почала активно відбирати землю у селян [12]. У ХІХ ст. за сприяння царського уряду відбувалося зміцнення російського землеволодіння за рахунок польських маєтностей. Проте автор зауважив, що російське поміщицьке землеволодіння не мало подальшого розвитку, бо переважна більшість маєтків роздробилися через шлюбні угоди чи продажі та знову повернулися до поляків. І. Рудченко зазначав, що російський елемент слабшав, натомість польський, отримавши підтримку та силу, витісняв російське землеволодіння. Навіть конфісковані і державні маєтки в південно-західних губерніях перейшли в польські руки. І. Рудченко зауважив, що саме так зміцнювалося польське землеволодіння в південно-західній губернії, послідовно та енергійно, і до 25 червня 1840 р., коли були введені в дію загальні російські закони, захищалося польськими законами, які запровадили при існуванні Польської держави. Автор звертає увагу на те, що незважаючи на участь у повстанні 1831 р., польська шляхта не втратила своїх привілеїв, поплатилися лише окремі особи, землі яких були конфісковані. Але на думку І. Рудченка, повстання вже продемонструвало ненадійність польсько-шляхетського елементу стосовно російської адміністрації. На підтвердження він наводить слова генерал-губернатора Д. Бібікова: «Если они сегодня покорны, то завтра, при благопріятных каких-нибудь обстоятельствах, могут изменить и чести и совести и Государю» $[12,15]$.

Процес проникнення російського землеволодіння на українські землі досліджував В. Садовський. На основі докладного вивчення законодавчих актів, що обмежували права польських землевласників на землеволодіння, він відзначав позитивну роль приватного землеволодіння, при цьому наголошуючи на культурній ролі російського землеволодіння. В. Садовський удався до аналізу обмежувального рескрипту генерал-губернатора 14 січня 1863 р., відповідно до якого в рамках заходів щодо збереження спокою в губернії було здійснено секвестр нерухомих польських маєтків. Положення щодо конфіскації майна, причетних до польського повстання, діяло до 3 лютого 1874 р. 10 грудня 1865 р. було заборонено поляками купувати нерухоме майно всіма способами, крім успадкування за законом. Натомість потрібно було всім 
власникам секвестрованих маєтків продати їх особам російського походження у дворічний термін. Правилами 27 грудня 1884 р. особам польського походження заборонено брати в запоруку нерухоме майно, знімати майно в довготривалу оренду, купувати землю. У 1891 р. заборонено передавати нерухоме майно особам польського походження в пожиттєве володіння. Поряд з обмежувальними заходами щодо польських власників проводилися заохочувальні заходи щодо осіб російського походження. Було складено положення про пільги покупцям непольського походження державних і приватних маєтностей. У 1865 р. державні та конфісковані маєтки було вирішено продавати без торгів і з розстрочкою платежу. Але цими правилами могли скористатися службовці у західних губерніях, військові і цивільні чини непольського походження, та всі особи російського походження, які отримали заслуги на державній службі. Російське керівництво турбувалося про організацію кредиту для російських поміщиків, з огляду на що було створено товариство покупців маєтків у Західній губернії. Товариство покупців приєднано до товариства взаємного поземельного кредиту, яке надавало кредит російським поміщикам, але натомість польським землевласникам це було заборонено. У такий спосіб відбувалося заохочення російського землеволодіння та витіснення польського. Автор наголосив на тому, що початок обмежувальної політики співпав з часом послаблення дворяського землеволодіння в цілому. Автор зауважив, що така підтримана урядом колонізація не могла призвести до створення російського землевласницького класу у краї, оскільки маєтки купувалися, але власники не оселялися в них, а віддавали в оренду полякам, тим, яких повиннні були витіснити. Як наслідок, на думку В. Садовського, заоохочення, пільги, позики не спромоглися створити в регіоні значного осілого російського землевласника $[13,45]$.

До проблеми законодавчої політики російської влади щодо польських землевласників звернувся В. Шульгін. Автор зазначав, що місцева адміністрація в середніх і нижчих інстанціях зосереджувалася в руках поляків. Офіційною мовою була російська, але використовувалася в документуванні у спотвореному вигляді. Законодавство в Південно-Західному краї являло собою суміш різночасових і різнонародних законопроектів. Нові закони існували поряд з литовським статутом і магдебурзьким правом. Право повної поземельної власності належало дворянським родам [15, 26]. Певний вплив поляки отримали через фінансові заходи. Було створено польський банк, що заволодів майже всіма фінансовими оборотами краю. Автор зазначив, що залучення капіталу зв'язувало південно-західних жителів міцними узами з Польщею, тим самим послаблюючи живий зв'язок з Росією.

Секретар Подільського губернського статистичного комітету, член Подільського єпархіального історико-статистичного комітету, Подільського історико-археологічного товариства В. Гульдман, обіймаючи різні чиновницькі посади, проблеми землеволодіння вивчав у контексті соціально-економічного розвитку Подільської губернії. Результатом цього стала поява довідкової книги щодо поміщицьких губерній у Подільській губернії. У книзі детально описано поміщицьке землеволодіння як у межах губернії, так і по повітах, перелічені прізвища власників маєтків, наведені відомості про кількість та обсяги землеволодінь [6]. 
Польському землеволодінню у загальноросійському контексті 3 економічної точки зору приділив увагу Тихон Осадчий, який походив із розкріпачених селян. Статистик, секретар Київського товариства сільського господарства, викладач, він $\epsilon$ автором близько 120 наукових праць, присвячених землеволодінню та землекористуванню. До дворянського землеволодіння звертався, порівнюючи його з селянським. Щодо польського землеволодіння, то він привернув увагу до розподілу землі між власниками у правобережній Україні $[10,8]$. Т. Осадчий, опрацювавши багатовимірний статистичний матеріал, показав переважання у Правобережній Україні приватного землеволодіння, яке, до того ж, мало тенденцію до зростання. Так, за десять років між сільськогосподарськими переписами 1877 та 1887 pp. у регіоні воно склало 307,6 тис. дес. (з 6 429,7 до 6 737,3 тис. дес.). Найпомітнішим воно було у Волинській губернії, відповідно 2 760,5 і 3 037,6 тис. дес. Автор простежує втрати дворян за 1877-1878 рр., незважаючи на які вони зберігали домінуючі позиції у землеволодінні. У загальному контексті дворянського землеволодіння розглянуті великі польські землевласники, які переважали у Південно-Західному краї [10, 9].

Економіко-статистичні дослідження на зламі XIX-XX ст. проводив фахівець в економічній статистиці, громадсько-політичний діяч Микола Порш, який підготував ряд досліджень, в яких, серед іншого, проаналізував зміни приватновласницького землеволодіння. У результаті співставлення показників автор показав, що протягом 18771905 рр. частка приватновласницької землі зменшилася з 48 до 46,5 \%. У Правобережній Україні, як він показав, дворянські землі обіймали 83,8 \% [11, 10]. Причому, у Правобережній Україні цей показник був найвищим серед українських губерній. Зокрема на Поділлі дворянам належало 80,5 \% приватної власності, 90,7 \% особистої, на Київщині - 73,1 та 84,9 \%, на Волині - 72,5 та 90,1 \%. Ці дані дають можливість характеризувати дворянське землеволодіння Правобережжя як потужне $[11,15]$.

Вплив реформи 1861 р. на аграрний стан Правобережної України дослідив статистик, економіст, викладач політекономії Юлій Янсон. Автор зазначав про легкий перехід земель від безгрошових власників до рук грошовитих осіб. Він зауважив, що ніде такий швидкий перехід не відбувався, як у Південно-Західній Україні [17, 270].

Таким чином, польське землеволодіння привертало увагу дореволюційних дослідників, серед яких були історики, економісти, статистики. У своїй більшості вони зверталися до загальних проблем землеволодіння та земелкористування у загальноросійському масштабі. Польське землеволодіння стало об'єктом уваги лише частини авторів. Вони приділили увагу історії його формування в українських землях, обмежувальній політиці російського уряду стосовно польських землевласників, змінам у землеволодінні на межі XIX-XX ст. Чи не найбільшим здобутком є нагромадження осяжного статистичного матеріалу, через що ці праці набували археографічного значення, створивши підгрунтя для наступних досліджень. Подальше опрацювання проблеми пов'язане з розширенням кола дослідників, які цікавилися історією польського землеволодіння, а також з визначенням внеску науковців наступних поколінь у його вивчення. 


\title{
Summary
}

The article deals with the analysis of the pre-revolutionary works on the issue of Polish land tenure in the provinces of Right-Bank Ukraine. Presented are the views of the researchers of the second half of the XIX - early XX centuries on the origin of the Polish land tenure and its development. The incorporation of Right-Bank Ukraine into the Russian Empire changed the position of Polish landowners, which contributed to the increased interest of the pre-revolutionary researchers.

The achievements of those authors are of great interest because they present a deep research into the phenomenon they could witness. The purpose of this paper is to analyze the works created in the second half of the XIX-early XX centuries on the problem of Polish land tenure in Ukrainian provinces. The paper is based on the principles of scientific objectivity and historicism; in the research, analytical-synthetic, statistical, historical-typological methods were applied. The paper presents a study of the pre-revolutionary authors' (mostly historians' and economists') works. In general, pre-revolutionary researchers were focused on Russia's landlord's economy, with Poland being mentioned only in its context, namely in the legislative system of the autocracy to weaken the Polish influence and reduce their land tenure. A characteristic feature of pre-revolutionary studies is that they provide us with a vast array of statistical material concerning the land tenure of RightBank Ukraine.

Key words: Right-bank Ukraine, Polish land tenure, pre-revolutionary researchers, historiography.

\begin{abstract}
Аннотация
Статья посвящена анализу работ дореволюционного периода по проблеме польского землевладения в губерниях Правобережной Украины. Освещены взгляды исследователей второй половины XIX - начала XX в. на наследие польского землевладения и его развитие. Вхождение Правобережной Украины в состав Российской империи изменило положение польских землевладельцев, что способствовало росту заинтересованности исследователей дореволючионной эпохи.

Работы дореволюичионых авторов представляют интерес, поскольку они исследовали современное им явление. Целью данного исследования является анализ работ, созданных во второй половине XIX - начале XX в. по проблеме польского землевладения в украинских губерниях. Статья опирается на принципы научной объективности и историзма, в процессе ее написания применены аналитико-синтетический, статистический, историко-типологический методы. Основу исследования составили труды дореволюционных авторов, среди которых преобладают историки и экономисты.

Освещены взгляды исследователей второй половины ХІХ - начала ХХвв. на происхождение, положение, эволючию польского землевладения. В целом дореволюиионные исследователи акцентировали внимание на дворянско-помещичьем хозяйстве России, а польское упоминалось исключительно в его контексте, в законодательной системе российского самодержавия относительно ослабления польского влияния и уменьшения их землевладения. Характерной особенностью дореволючионных исследователей стало то, что в их трудах мы находим большой массив статистического материала по землевладению Правобережной Украинь.
\end{abstract}

Ключевые слова: Правобережная Украина, польское землевладения, дореволючионные исследователи, историография. 


\section{ДЖЕРЕЛА ТА ЛІТЕРАТУРА}

1. Антонович В. Б. Моя сповідь. Моя сповідь. Вибрані історичні та публіцисттичні твори. Київ: Либідь, 1995. С. 78-90.

2. Бараненко С. Дворянство пореформеної доби в дореволюційній літературі. Icmoричні і політологічні дослідження. 2016. № 1(59). С. 100-109.

3. Борисевич С. О. Законодавче регулювання поземельних відносин у Правобережній Україні (1793-1886 роки). Київ: НАДУ, 2007. 422 с.

4. Грушевській М. Барськое староство (XV-XVIII в.). Историческіе очерки. Киев, 1984. 404 c.

5. Грушевський M. Історія України-Руси. URL: http://litopys.org.ua/hrushrus/ iur50203.htm

6. Гульдман В. К. Поместное землевладение в Подольской губернии. Настольносправочная книжка для землевладельцев и арендаторов. Каменец-Подольский: тип. С. П. Киржацкого, 1903. 867 с.

7. Кривошея I. I. Шляхта Уманщини в імперську добу (кінець XIX - перша третина ХІХ ст.). Умань: ВПЦ «Візаві», 2014. 254 с.

8. Криськов А. А. Землеволодіння і землекористування в губерніях Правобережної України другої половини XIX - початку XX ст. в історіографії дореволюційного періоду. Україна-Свропа-Світ. Міжнародний збірник наукових праџь. Серія: Історія, міжнародні відносини. 2015. Вип. 16(2). С. 83-90.

9. Лук'яненко В. П. Аграрне питання в громадсько-політичній думці України на початку XX ст.: автореф. дис. ... канд. іст. наук. Донецьк, 2009. 20 с.

10. Осадчий Т. И. Земля и земледельцы в Юго-Западном крае: на Украине, Подолии, Волыни. Опыт статистико-экономического исследования. Київ, 1899. 132 с.

11. Порш М. Статистика землеволодіння в 1905 р. і мобілізація земельної власності на Україні від 1877 р. і до 1905 р. Украӥна. 1907. № 4. С. 146-180.

12. Рудченко И. Записка о землевладении в Юго-Западном крає. Киев, 1882. 237 с.

13. Садовський В. Русское землевладъніе въ Правобережной Украине. Украиская Жизнь. Москва. 1913. № 1. С. 45-58.

14. Темірова Н. Р. Поміщики України в 1861-1917 рр.: соціально-економічна еволюція. Донецьк: ДонНУ, 2003. 319 с.

15. Шульгин В. Я. Юго-Западный край в последнее двадцатипятилетие (1838-1863). Київ: Тип. Ун-та, 1864. 254 с.

16. Щербак Н. О. Національне питання в політиці царизму у Правобережній Україні (кінець XVIII - початок XX ст.). Київ: Ризографіка, 2005. 616 с.

17. Янсон Ю. Э. Влияние реформы 1861 года на сельское хозяйство и хлебную торговлю в юго-западных губерниях. Труды императорского вольного экономического общества. СПб.: Общественная польза, 1868. С. 257-276. 


\section{References}

1. Antonovych, V. B. (1995). Moia spovid [My confession]. Moia spovid. Vybrani istorychni ta publitsystychni tvory. Kyiv: Lybid, 78-90.

2. Baranenko, S. (2016). Dvorianstvo poreformenoi doby v dorevoliutsiinii literaturi [The nobility of the post-reform period in pre-revolutionary literature]. Istorychni i politolohichni doslidzhennia, 1(59), 100-109.

3. Borysevych, S. O. (2007). Zakonodavche rehuliuvannia pozemelnykh vidnosyn u Pravoberezhnii Ukraini (1793-1886 roky) [Legislative regulation of land relations in the Right-Bank Ukraine (1793-1886)]. Kyiv: NADU.

4. Hrushevskyi, M. (1894). Barskoe starostvo (XV-XVIII v.). Ystorycheskie ocherky [Bar starosta. (XV-XVIII). Historical outline]. Kyev.

5. Hrushevskyi, M. Istoriia Ukrainy-Rusy [History of Ukraine-Ruthenia]. URL: http://litopys.org.ua/hrushrus/iur50203.htm

6. Huldman, V. K. (1903). Pomestnoe zemlevladenye v Podolskoi hubernyy. Nastolnospravochnaia knyzhka dlia zemlevladeltsev y arendatorov [Maetnye land tenure in Podolsk province. Nesting book for landowners and tenants]. Kamenets-Podolskyi: typ. S. P. Kyrzhatskoho.

7. Kryvosheia, I. I. (2014). Shliakhta Umanshchyny v impersku dobu (kinets XIX - persha tretyna XIX st.) [The Ulyanian nobility in the imperial day (the end of the XIXthe first third of the XIX)]. Uman: VPTs «Vizavi».

8. Kryskov, A. A. (2015). Zemlevolodinnia i zemlekorystuvannia v huberniiakh Pravoberezhnoi Ukrainy druhoi polovyny XIX - pochatku XX st. v istoriohrafii dorevoliutsiinoho periodu [Land tenure and land use in the provinces of the Right-Bank Ukraine in the XIX-XX centuries in the historiography of the pre-revolutionary period]. UkrainaYevropa-Svit. Mizhnarodnyi zbirnyk naukovykh prats. Seriia: Istoriia, mizhnarodni vidnosyny, 16(2), 83-90.

9. Lukianenko, V. P. (2009). Ahrarne pytannia v hromadsko-politychnii dumtsi Ukrainy na pochatku XX st. [The agrarian question in the public-political thought of Ukraine in the early twentieth century]: avtoref. dys. ... kand. ist. nauk. Donetsk.

10. Osadchyi, T. Y. (1899). Zemlia y zemledeltsi v Yuho-Zapadnom krae: na Ukrayne, Podolyy, Voliny. Opit statystyko-ekonomycheskoho yssledovanyia [Land and agricultural producers in the South-Western region: in Ukraine, Podillya, Volhynia. Experience statistical-economic studies]. Kyiv.

11. Porsh, M. (1907). Statystyka zemlevolodinnia v 1905 r. i mobilizatsiia zemelnoi vlasnosti na Ukraini vid 1877 r. i do 1905 r. [Land tenure statistics in 1905 and the mobilization of land ownership in Ukraine from 1877 to 1905]. Ukraina. 4, 146-180.

12. Rudchenko, Y. (1882). Zapyska o zemlevladenyy v Yuho-Zapadnom kraie [Statement of Land Tenure in the Southwest Territory] Kyiv.

13. Sadovskyi, V. (1913). Russkoe zemlevladenie vъ Pravoberezhnoi Ukrayne [Russian land tenure in Right-Bank Ukraine]. Ukrayskaia Zhyzn. Moskva, 1, 45-58. 
14. Temirova, N. R. (2003). Pomishchyky Ukrainy v 1861-1917 rr.: sotsialno-ekonomichna evoliutsiia [The landowners of Ukraine in 1861-1917: socio-economic evolution]. Donetsk: DonNU.

15. Shulhyn, V. Ya. (1864). Yuho-Zapadnyi krai v poslednee dvadtsatypiatyletye (18381863) [Southwestern edge in the last twenty-fifth anniversary (1838-1863)]. Kyiv: Typ. Un-ta.

16. Shcherbak, N. O. (2005). Natsionalne pytannia v politytsi tsaryzmu u Pravoberezhnii Ukraini (kinets XVIII - pochatok XX st.). [The national question in the policy of tsarism in the Right-Bank Ukraine (the end of the XVIII - the beginning of the XX)]. Kyiv: Ryzohrafika.

17. Ianson, Yu. E. (1868). Vlyianye reformi 1861 hoda na selskoe khoziaistvo y khlebnuiu torhovliu v yuho-zapadnikh hubernyiakh [Influence of the reform of 1861 on agriculture and bread trade in the southwestern provinces]. Trudi imperatorskoho volnoho ekonomycheskoho obshchestva. S.-Peterburh: Obshchestvennaia polza, 257-276.

УДК 94(477):63-058.12"18/19"

\section{МЕТАМОРФОЗИ АГРАРНОЇ ЕЛІТИ УКРАЇНСЬКИХ ГУБЕРНІЙ НА ЗЛАМI ХIX-XX СТ.}

\section{Темірова Надія}

Модернізаційні прочеси, щчо активізувалися у другій половині XIX - на початку XX ст., не оминули тогочасну аграрну еліту украӥнських губерній, репрезентовану, передусім, землевласниками дворянського походження. Стаття має на меті проаналізувати перетворення, яких вона зазнавала під впливом нових умов економічного та сочіального життя на зламі двох століть. Підмурок дослідження становить концепиія модернізаиії. Автор спирається на принципи наукової об'єктивності та історизму, послуговується історико-порівняльним, історико-типологічним, історико-генетичним, статистичним методами. За основу розвідки взяті статистичні, діловодні, публічистичні, особового походження джерела.

Дослідження дозволило акиентувати увагу на карколомних перетвореннях, яких зазнавала аграрна еліта, репрезентована до середини XIX cm. дворянами, внаслідок скасування кріпацтвв, аграрної кризи кіния XIX ст., селянського руху на початку XX ст., Столипінської реформи, Першої світової війни. Найочевиднішими зрушеннями були швидке скорочення дворянського землеволодіння, поповнення аграрної еліти «новими» землевласниками, підприємницька переорієнтація частини поміщиків. Новим умовам відповідала професіоналізація управління господарством, застосування нових технологій у сільському господарстві, розвиток промислового підприємництва, активна доброчинність, захист своӥх прав через об'єднання у представницькі організації. Показано, щчо в означений період аграрна еліта рухалася від привілейованого стану до класу аграрїв-підприємиів, які мусили орієнтуватися в умовах вільної конкуренції та реагувати на запити суспільства, але перетворення перервали револючійні 1917-1921 рр., наприкінці яких аграрна еліта була ліквідована. Перспективи дослідження пов'язані з опрацюванням наративних джерел щуодо подолання криз аграрної еліти.

Ключові слова: аграрна еліта, перетворення, модернізація, криза, соціальна еволючія, украӥнські губернії. 